\title{
(2) OPEN ACCESS \\ Associations between earplug use and hearing loss in ROK military personnel
}

\author{
Hwi Jun Kim (1), ${ }^{1}$ S Y Oh, ${ }^{1}$ S Y Won, ${ }^{2}$ H J Kim, ${ }^{3}$ T K Kim, ${ }^{4}$ B C Ko, ${ }^{5}$ S Y Woo, ${ }^{6}$ E-C Park ${ }^{7}$
}

'Department of Public Health, Graduate School, Yonsei University, Seodaemun-gu, Seoul, Republic of Korea 2Division of Management Logistics, Korea Ministry of National Defense, Seoul, Republic of Korea

${ }^{3}$ Division of Medical Corps, Second Operational Command, Daegu, Republic of Korea

${ }^{4}$ Secretary's office, Armed Forces Medical Command, Seongnam,

Republic of Korea

${ }^{5}$ Department of Operation, 7th Division Medical Detachment, Seoul, Republic of Korea ${ }^{6}$ Department of Nursing, Yonsei University, Seodaemun-gu, Seoul, Republic of Korea ${ }^{7}$ Department of Preventive Medicine, Yonsei University College of Medicine, Seodaemun-gu, Seoul, Republic of Korea

\section{Correspondence to}

Professor E-C Park, Department of Preventive Medicine, Yonsei University College of Medicine Seodaemun-gu 03722, Republic of Korea; ecpark@yuhs.ac

Received 20 November 2019 Revised 14 December 2019 Accepted 17 December 2019

Check for updates

(c) Author(s) (or their employer(s)) 2020. Re-use permitted under CC BY-NC. No commercial re-use. See rights and permissions. Published by BMJ.

To cite: $\mathrm{Kim} \mathrm{HJ}$, Oh SY, Won SY, et al. BMJ Mil Health Epub ahead of print: [please include Day Month Year]. doi:10.1136/

jramc-2019-001378

\section{ABSTRACT}

Introduction The easiest way to prevent noise-induced hearing loss (NIHL) is to wear earplugs. The Republic of Korea (ROK) Ministry of National Defense (MND) is supplying earplugs to prevent NIHL, but many patients still suffer from this. We speculated that earplugs would have a high NIHL rate, depending on the rate of use of earplugs, regardless of the rate of supply. Therefore, we conducted this study to investigate the relationship between the use of earplugs and hearing loss by ROK military personnel.

Methods The study used data from the Military Health Survey conducted in 2014-2015, which included 13470 questionnaires completed by ROK military personnel. Hearing loss and earplug use were self-reported. Logistic regression analysis was used to assess associations between earplug use and hearing loss.

Results The study sample included 13470 ROK military personnel (response rate of 71.2\%) (Army, $8330(61.8 \%$ ); Navy/Marines, 2236 (16.6\%); and Air Force, 2904 $(21.6 \%))$. Overall, $18.8 \%$ of Korean military personnel reported that they always wore earplugs, and 2.8\% reported hearing loss. In logistic regression analysis, there were significant differences in the rates of hearing loss associated with wearing earplugs sometimes $(O R=1.48$, $95 \% \mathrm{Cl} 1.07$ to 2.05$)$ and never wearing earplugs $(\mathrm{OR}=1.53,95 \% \mathrm{Cl} 1.12$ to 2.10$)$. In subgroup analysis, in Air Force, non-combat branch, forward area and longterm military service personnel increased hearing loss was associated with not wearing earplugs.

Conclusion Our study confirmed that within the ROK military, there is an association between hearing loss and lack of earplug use. In the ROK MND, Army, Navy/Marines and Air Force headquarters must provide guidelines for the use of earplugs during field training to protect military personnel's hearings and, if necessary, need to be regulated or institutionalised.

\section{INTRODUCTION}

Noise-induced hearing loss (NIHL) is a sensorineural hearing deficit that begins at the higher frequencies $(3-6 \mathrm{kHz})$ and develops gradually as a result of chronic exposure to excessive sound levels. ${ }^{1}$ In addition, sudden noise of $70 \mathrm{~dB}$ or more can have a critical effect on the body. ${ }^{2}$ Although the hearing loss is typically symmetric, noise from such sources as firearms or sirens may produce an asymmetrical loss.

Due to the nature of the profession, the main task is for military personnel to use guns and artilleries. However, it has been reported that the noise level for a single gunshot is $75-90 \mathrm{~dB}$ for rifle shot and $75 \mathrm{~dB}$ for carbines. In addition, the M-16 rifle fire sounds are $170 \mathrm{~dB}$ and the artillery fire sounds are

\section{Key messages}

Overall, $2.8 \%$ of the Republic of Korea (ROK) military personnel surveyed reported that they had experienced hearing loss.

- Close to half of the 13470 ROK military personnel surveyed reported that they did not wear earplugs at all $(6090,45.2 \%)$.

- Not wearing earplugs was significantly associated with hearing loss.

- The hearing loss and the low rate of earplug use in the ROK military identified in the present study can be used as a basis for strategies designed to increase the use of earplugs in the organisation.

$180 \mathrm{~dB}$ of noise, which can cause NIHL. ${ }^{3}$ Thus, according to data provided by the Republic of Korea (ROK) Armed Forces Medical Command (AFMC), otolaryngologists in the military are estimated to treat more than 110000 patients each year for blast-related ear injuries and/or hearing loss induced by rifle fire or artillery training. ${ }^{4}$

The easiest way to prevent way to prevent NIHL is to wear earplugs. ${ }^{5-7}$ Therefore, the ROK Army, Navy/Marines and Air Force provide military personnel with earplugs as a way of personal hearing protection and provide education to prevent NIHL. ${ }^{8}$ However, NIHL continues to arise from ROK military personnel. ${ }^{9}$

ROK military research on NIHL continues. However, unlike the case of another nation's military attempting a multifaceted approach to the NIHL, ${ }^{10-12}$ the ROK military focused primarily on the Air Force's hearing loss. ${ }^{13-15}$ There has been little research on the hearing of the army and navy. Therefore, we conducted this study to confirm how the use of earplugs in the Army, Navy/Marines and Air Force is related to NIHL.

\section{METHODS}

\section{Study participants}

Data were obtained from the 2014-2015 Military Health Survey (MHS), which is a cross-sectional survey of military personnel that was conducted by the School of Military Medicine to investigate health determinants. The survey was designed to acquire self-reported data via a questionnaire. Raw data were obtained from the Korean Military Medical School with the dean's approval. Because the 2014 MHS was an anonymous selfadministered survey, individual responses cannot be linked to specific personnel or medical records. 
Table 1 General characteristics of study observations (Military Health Survey 2014-2015)

\begin{tabular}{|c|c|c|c|c|}
\hline \multirow[b]{3}{*}{ Variable } & \multicolumn{3}{|l|}{ Hearing loss } & \multirow[b]{3}{*}{$P$ value } \\
\hline & Total & Yes & No & \\
\hline & $\mathrm{n}(\%)$ & $\mathrm{n}(\%)$ & $\mathrm{n}(\%)$ & \\
\hline Earplug use & & & & 0.0353 \\
\hline Always & $2528(18.8)$ & $52(2.1)$ & 2476 (97.9) & \\
\hline Sometimes & $4852(36.0)$ & $140(2.9)$ & $4712(97.1)$ & \\
\hline None & $6090(45.2)$ & $186(3.1)$ & $5904(97.0)$ & \\
\hline Sex & & & & 0.3596 \\
\hline Man & $13080(97.1)$ & $370(2.8)$ & $12710(97.2)$ & \\
\hline Woman & $390(2.9)$ & $8(2.1)$ & $382(98.0)$ & \\
\hline Marital status & & & & $<0.0001$ \\
\hline Married & $1630(12.1)$ & $88(5.4)$ & $1542(94.6)$ & \\
\hline Single (divorced, separated or bereaved) & $306(2.3)$ & $22(7.2)$ & $284(92.8)$ & \\
\hline Never married & $11534(85.6)$ & $268(2.3)$ & $11266(97.7)$ & \\
\hline Educational level & & & & 0.5636 \\
\hline High school or less & $2484(18.4)$ & $74(3.0)$ & $2410(97.0)$ & \\
\hline College or more & $10986(81.6)$ & $304(2.80$ & $10682(97.2)$ & \\
\hline Military type & & & & 0.8874 \\
\hline Army & $8330(61.8)$ & $230(2.8)$ & $8100(97.2)$ & \\
\hline Navy and Marines & $2236(16.6)$ & $66(3.0)$ & $2170(97.1)$ & \\
\hline Air Force & $2904(21.6)$ & $82(2.8)$ & $2822(97.2)$ & \\
\hline Branch & & & & 0.3112 \\
\hline Combat & $8740(64.9)$ & $236(2.7)$ & $8504(97.3)$ & \\
\hline Non-combat & $4730(35.1)$ & $142(3.0)$ & $4588(97.0)$ & \\
\hline Rank & & & & 0.0023 \\
\hline Warrant officer and commissioned officer (W1-06) & $1798(13.4)$ & $58(3.2)$ & $1740(96.8)$ & \\
\hline Non-commissioned officer (E5-E9) & $3378(25.1)$ & $118(3.5)$ & $3260(96.5)$ & \\
\hline Enlisted soldier (E3 and E4) & 3958 (29.4) & $110(2.8)$ & $3848(97.2)$ & \\
\hline Enlisted soldier (E1 and E2) & $4336(32.2)$ & $92(2.1)$ & $4244(97.9)$ & \\
\hline Working area & & & & 0.3557 \\
\hline Forward area & $8922(66.2)$ & $242(2.7)$ & $8680(97.3)$ & \\
\hline Rear area & $4548(33.8)$ & $136(3.0)$ & $4412(97.0)$ & \\
\hline Service classification & & & & $<0.0001$ \\
\hline Long-term military service & $2922(21.7)$ & $150(5.1)$ & $2772(94.9)$ & \\
\hline Short-term military service & $10548(78.3)$ & $228(2.2)$ & $10320(97.8)$ & \\
\hline Working time (hour/week) & & & & 0.4297 \\
\hline$\leq 48$ & $6684(49.6)$ & $180(2.7)$ & $6504(97.3)$ & \\
\hline$\geq 49$ & $6786(50.4)$ & $198(2.9)$ & $6588(97.1)$ & \\
\hline Total & $13470(100.0)$ & $378(2.8)$ & $13092(97.2)$ & \\
\hline
\end{tabular}

The survey was conducted every year for 5000 officers, warrant officers, non-commissioned officers (NCOs) and 5000 enlisted soldiers. The total number of survey participants during the 2 years of the study was 14244 (response rate of 71.2\%) (1914 officers and warrant officers, 3604 NCOs and 8726 enlisted soldiers). Respondents who used medical services pertaining to hearing loss over the past year were tabulated, as were those who answered questions relating to wearing earplugs.

Only respondents who answered questions identifying their sex, marital status, educational level, military type, branch, rank, working area, service classification and working time were included in the current study. The final analysis dataset included 13470 military personnel, $94.6 \%$ of all survey respondents (1798 officers and warrant officers, 3378 NCOs and 3378 enlisted soldiers).

\section{Variables}

Hearing loss was the main dependent variable in the current study. The MHS investigated this via the question 'Check all diseases you have experienced over the past year'. The analyses of hearing loss in the current study was based on respondents who checked 'hearing loss' in response to that prompt. The interesting variable was earplug use. The relevant question in the survey was 'Do you wear earplugs?'. Possible answers were 'always wear earplugs', 'sometimes wear earplugs', 'often do not wear earplugs', 'do not wear earplugs' and 'not applicable'. We distinguished between sometimes wear earplugs, often do not wear earplugs and sometimes wear earplugs. Not applicable was excluded from the analysis.

Several covariates were assessed, including sociodemographic, military-related and health-related characteristics. Sociodemographic characteristics included sex (male and female), marital status (married, previously married (divorced, separated or bereaved) or unmarried) and education level (high school or less, college or above). Military-related characteristics included military type (Army, Navy/Marines or Air Force), branch (combat, technique/administration or special), rank (warrant officer or commissioned officer (W1-O6), NCO (E5-E9), or enlisted 
Table 2 Factors associated with hearing loss and whether to use earplugs (Military Health Survey 2014-2015)

\begin{tabular}{|c|c|c|}
\hline \multirow[b]{2}{*}{ Variables } & Hearing loss & \multirow[b]{2}{*}{$P$ value } \\
\hline & Adjusted OR $(95 \% \mathrm{Cl})$ & \\
\hline \multicolumn{3}{|l|}{ Earplug use } \\
\hline Always & 1.00 & \\
\hline Sometimes & 1.48 (1.07 to 2.05$)$ & 0.0185 \\
\hline None & 1.53 (1.12 to 2.10$)$ & 0.0081 \\
\hline \multicolumn{3}{|l|}{ Sex } \\
\hline Man & 1.00 & \\
\hline Woman & 1.54 (0.74 to 3.24$)$ & 0.2516 \\
\hline \multicolumn{3}{|l|}{ Marital status } \\
\hline Married & 1.00 & \\
\hline Single (divorced, separated or bereaved) & 1.38 (0.85 to 2.26$)$ & 0.1963 \\
\hline Never married & 0.69 (0.47 to 0.99$)$ & 0.0462 \\
\hline \multicolumn{3}{|l|}{ Educational level } \\
\hline High school or less & 0.92 (0.70 to 1.20$)$ & 0.5262 \\
\hline College or more & 1.00 & \\
\hline \multicolumn{3}{|l|}{ Military type } \\
\hline Army & 1.16 (0.82 to 1.64$)$ & 0.409 \\
\hline Navy and Marines & 1.06 (0.74 to 1.52$)$ & 0.7414 \\
\hline Air Force & 1.00 & \\
\hline \multicolumn{3}{|l|}{ Branch } \\
\hline Combat & 1.16 (0.90 to 1.48$)$ & 0.2489 \\
\hline Non-combat & 1.00 & \\
\hline \multicolumn{3}{|l|}{ Rank } \\
\hline $\begin{array}{l}\text { Warrant officer and commissioned officer } \\
\text { (W1-06) }\end{array}$ & 1.00 & \\
\hline Non-commissioned officer (E5-E9) & 1.14 (0.80 to 1.61$)$ & 0.4675 \\
\hline Enlisted soldier (E3 and E4) & 2.58 (1.57 to 4.25$)$ & 0.0002 \\
\hline Enlisted soldier (E1 and E2) & 1.92 (1.15 to 3.18$)$ & 0.0123 \\
\hline \multicolumn{3}{|l|}{ Working area } \\
\hline Forward area & $1.06(0.80$ to 1.40$)$ & 0.6752 \\
\hline Rear area & 1.00 & \\
\hline \multicolumn{3}{|l|}{ Service classification } \\
\hline Long-term military service & 1.00 & \\
\hline Short-term military service & 0.27 (0.17 to 0.44$)$ & $<0.0001$ \\
\hline \multicolumn{3}{|l|}{ Working time (hour/week) } \\
\hline$\leq 48$ & 1.03 (0.83 to 1.28$)$ & 0.7955 \\
\hline$\geq 49$ & 1.00 & \\
\hline
\end{tabular}

soldier (E3 and E4) or enlisted soldier (E1 and E2)), working area (forward area or rear area), service classification (long-term military service or short-term military service) and working time $(\leq 48$ or $\geq 49)$.

\section{Statistical analysis}

The $\chi^{2}$ test and logistic regression analysis were used to analyse associations between earplug use and hearing loss. The $\chi^{2}$ test was used to investigate the significance of differences in hearing loss, depending on earplug use. Logistic regression analysis was used to determine ORs and 95\% CIs. Subgroup analysis of earplug use was performed based on hearing loss, sex, marital status, educational level, military type, branch, working area and service classification. Statistical analyses were performed using SAS software V.9.4. A p value of $<0.05$ was deemed to indicate statistical significance.

\section{RESULTS}

The sample included 13470 military personnel (Army, 8330 (61.8\%); Navy/Marines, 2236 (16.6\%); and Air Force, 2904
Table 3 Factors of hearing loss depending on whether to use earplugs (Military Health Survey 2014-2015)

\begin{tabular}{|c|c|c|c|}
\hline \multirow[b]{3}{*}{ Variables } & \multicolumn{3}{|l|}{ Hearing loss } \\
\hline & $\begin{array}{l}\text { Always use } \\
\text { earplugs }\end{array}$ & $\begin{array}{l}\text { Sometimes use } \\
\text { earplugs }\end{array}$ & $\begin{array}{l}\text { Do not use } \\
\text { earplugs }\end{array}$ \\
\hline & Adjusted OR & $\begin{array}{l}\text { Adjusted OR } \\
(95 \% \mathrm{Cl})\end{array}$ & $\begin{array}{l}\text { Adjusted OR } \\
(95 \% \mathrm{Cl})\end{array}$ \\
\hline \multicolumn{4}{|l|}{ Sex } \\
\hline Man & 1 & 1.44 (1.04 to 1.99$)$ & 1.51 (1.10 to 2.07$)$ \\
\hline Woman & 1 & - & - \\
\hline \multicolumn{4}{|l|}{ Marital status } \\
\hline Married & 1 & 1.01 (0.51 to 2.00$)$ & 1.81 (0.98 to 3.32$)$ \\
\hline $\begin{array}{l}\text { Single (divorced, separated or } \\
\text { bereaved) }\end{array}$ & 1 & 2.04 (0.43 to 9.64$)$ & 0.83 (0.21 to 3.28$)$ \\
\hline Never married & 1 & 1.68 (1.14 to 2.48$)$ & 1.55 (1.05 to 2.28$)$ \\
\hline \multicolumn{4}{|l|}{ Educational level } \\
\hline High school or less & 1 & 1.03 (0.47 to 2.26$)$ & 2.00 (0.99 to 4.03$)$ \\
\hline College or more & 1 & 1.58 (1.10 to 2.26$)$ & 1.40 (0.98 to 2.00$)$ \\
\hline \multicolumn{4}{|l|}{ Military type } \\
\hline Army & 1 & 1.33 (0.89 to 1.98$)$ & 1.32 (0.89 to 1.95$)$ \\
\hline Navy and Marines & 1 & $1.43(0.70$ to 2.90$)$ & $0.80(0.38$ to 1.65$)$ \\
\hline Air Force & 1 & 1.77 (0.70 to 4.47$)$ & 3.41 (1.44 to 8.06$)$ \\
\hline \multicolumn{4}{|l|}{ Branch } \\
\hline Combat & 1 & 1.42 (0.96 to 2.09 ) & 1.39 (0.95 to 2.03$)$ \\
\hline Non-combat & 1 & 1.59 (0.87 to 2.91$)$ & $1.80(1.01$ to 3.21$)$ \\
\hline \multicolumn{4}{|l|}{ Working area } \\
\hline Forward area & 1 & 1.52 (1.01 to 2.30$)$ & $1.68(1.13$ to 2.50$)$ \\
\hline Rear area & 1 & 1.46 (0.86 to 2.48 ) & 1.36 (0.81 to 2.28$)$ \\
\hline \multicolumn{4}{|l|}{ Service classification } \\
\hline Long-term military service & 1 & 1.43 (0.85 to 2.43$)$ & 1.88 (1.15 to 3.08$)$ \\
\hline Short-term military service & 1 & 1.49 (0.98 to 2.26$)$ & 1.31 (0.87 to 1.98$)$ \\
\hline
\end{tabular}

(21.6\%)). Overall, $2.8 \%$ of military personnel reported that they had experienced hearing loss. Most military personnel either sometimes wore earplugs or never wore earplugs. Of the total 13470 respondents, 2528 (18.8\%) reported that they always wore earplugs; $4852(36.0 \%)$ reported that they sometimes wore them; and 6090 (45.2\%) reported that they never wore them (Table 1).

The results of the logistic regression analysis pertaining to hearing loss are shown in Table 2. In the logistic regression analysis, there were significant differences in the rates of hearing loss associated with wearing earplugs sometimes (OR $=1.48,95 \% \mathrm{CI}$ 1.07 to 2.05$)$ and never wearing earplugs $(\mathrm{OR}=1.53,95 \% \mathrm{CI}$ 1.12 to 2.10$)$. Enlisted soldiers were more likely to experience hearing loss than warrant officers and commissioned officers (enlisted soldiers (E3 and E4), $\mathrm{OR}=2.58,95 \% \mathrm{CI} 1.57$ to 4.25 ; enlisted soldiers (E1 and $E 2), O R=1.92,95 \%$ CI 1.15 to 3.18 ).

Data reflecting differences between those who reported always wearing earplugs and those who reported sometimes wearing them or never wearing them are shown in Table 3. In the Air Force, personnel who never wore earplugs were more likely to experience hearing loss than those who always wore them $(\mathrm{OR}=3.41,95 \% \mathrm{CI} 1.44$ to 8.06$)$. With regard to branch, noncombat personnel who never wore earplugs were more likely to experience hearing loss than those who always wore them $(\mathrm{OR}=1.80,95 \% \mathrm{CI} 1.01$ to 3.21$)$. With regard to working area, forward area personnel who sometimes wore earplugs and those who never wore them were more likely to experience hearing loss than those who always wore them (sometimes wore earplugs group, $\mathrm{OR}=1.52,95 \% \mathrm{CI} 1.01$ to 2.30 ; never wore earplugs group, $\mathrm{OR}=1.68,95 \% \mathrm{CI} 1.13$ to 2.50$)$. With regard to service classification, long-term military service personnel were more 
likely to have experienced hearing loss $(\mathrm{OR}=1.88,95 \% \mathrm{CI} 1.15$ to 3.08$)$.

\section{DISCUSSION}

This study can be used as a basis for demonstrating the effects of wearing earplugs during training. ROK Defense, Army, Navy/ Marines and Air Force Command provide earplugs to protect the military personnel's hearing. However, in our analysis, $81.2 \%$ of military personnel responded they never use or sometimes use earplugs. Hearing loss was most likely in military personnel who never use earplugs or sometimes use earplugs. This suggests that the continued use of earplugs is important.

We suggest the following points. First, efforts to protect military personnel's hearings must be continued. Ministry of National Defense should continue to provide earplugs to military personnel so that they are not exposed to hearing loss. Second, military personnel should be educated on the importance of continued use of earplugs. Our study found that the group which occasionally wears earplugs was 1.48 times more likely to have a hearing loss than the group which always uses earplugs. The group which never uses earplugs was 1.53 times more likely to have a hearing loss than the group which always uses earplugs. This suggests that if you do not continue to use earplugs, your exposure to hearing loss is similar to the never-use group. Therefore, earplugs should always be worn to protect the military personnel's hearing. Finally, it is necessary to analyse the cause of the poor use of earplugs. Only $18.8 \%$ of military personnel in our study said they always used earplugs. It is necessary to examine when the use of earplugs does cause discomfort or dissatisfaction for military personnel, and if evidence is found, efforts will be needed to improve them.

The present study had some limitations. First, MHS asked if military personnel had hearing loss and if they wore earplugs in general. Because the current study utilised self-reported data, recall bias can occur at this point. Second, if there was any dissatisfaction with the earplugs supplied, self-reported data may reflect a tendency to under-report usage. Third, because this study is a cross-sectional study, there was no capacity to thoroughly investigate causal relationships between hearing loss and earplug use in the ROK military. A randomised controlled trial is needed to investigate such relationships, but notably, such trials involving military personnel are very limited in the ROK military. Therefore, it is necessary to accumulate long-term data such as those derived from military defence cohorts, to analyse the phenomena of interest. Fourth, it would have been better if the study analysed the effect of wearing earplugs on the severity of hearing loss. However, due to the limitation of the data, the analysis according to the severity could not be performed. Lastly, the sample population consisted entirely of ROK military personnel so the results of the study may not be readily generalisable to other groups.

Despite the aforementioned limitations, the present study had several strengths. The data used were sourced from the largest survey ever conducted by the ROK AFMC, which was undertaken to investigate health behaviours in military personnel and facilitate the calculation of health-related statistics required for health business planning and evaluation. That survey was administered to more than 13000 military personnel and incorporated the selection of representative samples with regard to distributions of class, health status and region in the ROK Army, Navy/Marines and Air Force. Therefore, the data were derived from the largest healthcare-related survey conducted in military personnel. Another strength of the study is that as well as ROK
Air Force personnel, it incorporated ROK Army and ROK Navy/ Marines personnel. Hitherto, studies investigating hearing loss in the ROK military have mainly focused on the Air Force. To the best of our knowledge, this is the first study to investigate hearing loss and earplug use in the ROK Army, Navy/Marines and Air Force.

\section{CONCLUSION}

Our study confirmed that within the ROK military, there is an association between hearing loss and lack of earplug use. In the ROK Defense, Army, Navy/Marines and Air Force headquarters, consideration of mandatory equipment wearing and modernisation of equipment is necessary for the protection of military personnel's hearing.

Contributors HwJK: conceptualisation, study design, data collection, overview, literature review, formal analysis and write-up. SYO: methodology and review. SYW: data collection, analysis and review. HaJK: study design, data collection and review. TKK and BCK: data collection and review. SYW: review and write-up. E-CP: supervision.

Funding The authors have not declared a specific grant for this research from any funding agency in the public, commercial or not-for-profit sectors.

Competing interests None declared.

Patient consent for publication Not required.

Provenance and peer review Not commissioned; internally peer reviewed.

Data availability statement Data are available upon reasonable request.

Open access This is an open access article distributed in accordance with the Creative Commons Attribution Non Commercial (CC BY-NC 4.0) license, which permits others to distribute, remix, adapt, build upon this work non-commercially, and license their derivative works on different terms, provided the original work is properly cited, appropriate credit is given, any changes made indicated, and the use is non-commercial. See: http://creativecommons.org/licenses/by-nc/4.0/.

\section{ORCID iD}

Hwi Jun Kim http://orcid.org/0000-0001-7007-8442

\section{REFERENCES}

1 Rabinowitz PM. Noise-induced hearing loss. Am Fam Physician 2000;61:2759-60.

2 Babisch W, Beule B, Schust M, et al. Traffic noise and risk of myocardial infarction. Epidemiology 2005; 16:33-40.

$3 \mathrm{Kim} \mathrm{H}$, Cho SH, Lim HS. The effect of gunshot or cannonade training during military service on hearing threshold levels. J Prev Medi 1991;24:86-92.

4 Armed Forces Medical Command. Top 10 departments of military hospital care (2015 2017); 2019

5 Hinchcliffe R. Occupational deafness: occupational noise-induced hearing loss. . SAGE Publications, 1967: 60. 1111-7.

6 Goldner A. Occupational deafness, with special reference to chronic occupational deafness. Arch Otolaryngol 1945;42:407-11

7 Sulkowski WJ, Szymczak W, Kowalska S, et al. Epidemiology of occupational noiseinduced hearing loss (ONIHL) in Poland. Otolaryngol Pol 2004;58:233-6.

8 Jones GH, Pearson CR. The use of personal hearing protection in hostile Territory and the effect of health promotion activity: advice falling upon deaf ears. J R Army Med Corps 2016;162:280-3.

9 Kim K. Tinnitus disability compensation: focusing on tinnitus disorder caused by military noise in veterans. Audiol Speech Res 2017;13:209-15.

10 Job A, Cardinal F, Michel H, et al. Tinnitus and associated handicaps in the French mountain Artillery: assessment by the tinnitus handicap inventory. Mil Med 2018;183:e302-6.

11 Patil ML, Breeze J. Use of hearing protection on military operations. J R Army Med Corps 2011;157:381-4.

12 Ramsey R, Greenough J, Breeze J. Noise-Induced hearing loss in the military dental setting: a UK legislative perspective. J R Army Med Corps 2019:jramc-2018-001150.

13 Jeong JA, Han SK, Hong OS, et al. Prevalence and risk factors of noise-induced hearing loss among the Republic of Korea air force pilots. J Military Nurs Res 2013;31:102-17.

14 Kim S-K, Lee S-H, Kim D-S. Risk analysis of hearing loss in the air base. J Korea Inst Military Sci Technol 2012;15:186-92.

15 Lee CY. Noise induced hearing loss of 3 military workers that satisfied guidelines of occupational disease in Korean occupational safety \& health act. Aeromedical center 2000;10:347-50. 